\title{
Correction: Comparative chromosome mapping of repetitive sequences. Implications for genomic evolution in the fish, Hoplias malabaricus
}

\author{
Marcelo B Cioffi ${ }^{1}$, Cesar Martins ${ }^{2 *}$ and Luiz AC Bertollo ${ }^{1}$
}

\section{Correction}

After the publication of this work [1] the following errors were brought to the authors' attention: Figure two contained a mistake that occurred during the editing process and karyotype assemblage so that two chromosome pairs $\left(\mathrm{X}_{1}\right.$ and $\left.\mathrm{X}_{2}\right)$ were inadvertently duplicated in the karyotype of the female specimen - karyomorph $\mathrm{D}$. The correct figure is given below (Figure 1).

The authors would like to apologise for any confusion caused by this mistake.

Received: 5 April 2013 Accepted: 5 April 2013

Published: 9 April 2013

\section{References}

1. Cioffi MB, Martins C, Bertollo LAC: Comparative chromosome mapping of repetitive sequences. Implications for genomic evolution in the fish, Hoplias malabaricus. BMC Genet BMC Genetics 2009, 10:34.

\footnotetext{
* Correspondence: cmartins@ibb.unesp.br

${ }^{2}$ Departamento de Morfologia, UNESP - Universidade Estadual Paulista, Instituto de Biociências, Botucatu, SP, Brazil

Full list of author information is available at the end of the article
}

Submit your next manuscript to BioMed Central and take full advantage of:

- Convenient online submission

- Thorough peer review

- No space constraints or color figure charges

- Immediate publication on acceptance

- Inclusion in PubMed, CAS, Scopus and Google Scholar

- Research which is freely available for redistribution

Submit your manuscript at www.biomedcentral.com/submit

( Biomed Central 


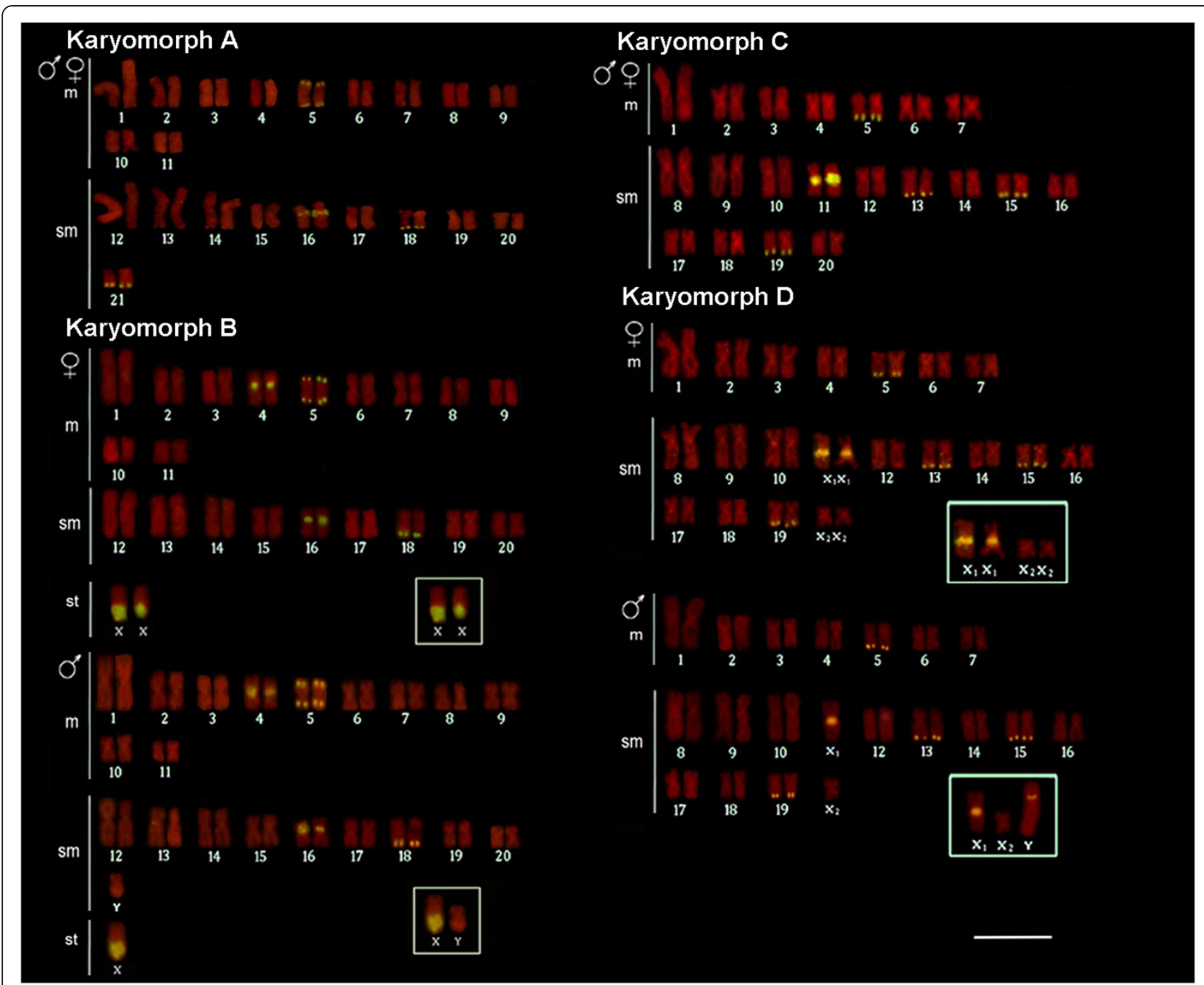

Figure 1 Karyotypes of Hoplias malabaricus (karyomorphs A-D) arranged from chromosomes probed with 18S rDNA (yellow signals) and counterstained with propidium iodide. The sex chromosomes of karyomorphs $B$ and $D$ are boxed. Bar $=5 \mu \mathrm{m}$. 